\title{
The acceptability of yellow mealworm as chicken feed: a case study of small-scale farmers in South Africa
}

\author{
Letlhogonolo Selaledi $^{1,2}$ (D), Matome Maake ${ }^{1}$ and Monnye Mabelebele ${ }^{7^{*}}$ (D)
}

\begin{abstract}
Background: Small-scale poultry farming plays a major role as a source of income for farmers through the sale of birds and eggs. Furthermore, in households' poultry products are a valuable source of protein in the diet-especially in low-income communities. However, these farmers are facing a challenge with the rising cost of conventional feed. Climate change and global warming play a role in changing farming activities and affecting household food security. Therefore, replacing traditional ingredients with insects in chicken diets is gaining popularity worldwide. The purpose of this study was to assess the willingness of small-scale poultry farmers to adopt the use of yellow mealworm in diets for chickens. A total number of 107 farmers in the City of Tshwane Metropolitan Municipality were selected using snowball sampling and were interviewed face to face using a semi-structured questionnaire.

Results: Descriptive statistics and binary logistic regression were used to analyse the data. The results of the study showed that $72 \%$ of respondents, the majority of whom were male, were willing to adopt mealworm as poultry feed. About $51 \%$ of the participants were willing to eat chicken that was reared using mealworms, even though $85 \%$ had not seen mealworms before. Furthermore, it was found that farmers who used mixed corn and who had secondary education were more willing to adopt mealworms as an alternative protein source in chicken feed.
\end{abstract}

Conclusion: Small-scale poultry farmers in Tshwane accept the use of mealworm as chicken feed. It is recommended that the early adopters of mealworms as poultry feed be profiled so that communication strategies can be developed to deal with the fears and attitudes of farmers who are not willing to adopt mealworms as poultry feed. Since the majority of the farmers who are willing to adopt mealworm had secondary education, it would be beneficial if smallscale poultry farmers are educated about the benefits of using yellow mealworm as a substitute in poultry feed.

Keywords: Poultry, Farmer, Edible insects, Mealworm, Tenebrio molitor, Entomophagy

\section{Background}

The animal feed industry is a billion-dollar market globally. The poultry sector is the biggest consumer of animal feed, with countries such as China, the United States of America (USA) and Brazil being the main producers. South Africa is the largest producer and consumer of

*Correspondence: mabelebelem@gmail.com

${ }^{1}$ College of Agriculture and Environmental Sciences, University of South Africa, Unisa Science Campus, Florida, Johannesburg, South Africa

Full list of author information is available at the end of the article animal feed on the African continent [1]. Maize and soya bean are the major ingredients used in the feed industry, with broilers and layers as the main consumers of these products [2]. Although fishmeal and soya bean are important sources of high-quality protein in poultry feeds, concerns about their costs and sustainability are making them less attractive feed materials. Replacing soya bean and fishmeal with insects in poultry diets is a practice that is gaining momentum. This is because insects are not only a good source of protein; they also have a low initial investment requirement; therefore, their use in 
poultry diets could benefit commercial as well as smallholder farmers from low-income countries [3, 4]. When included in poultry diets, edible insects have the potential to simplify issues related to food security in developing countries [5]. Over the years, there has been much debate on food security. However, there is a lack of consensus on how to establish which countries are in need of improved food security status [6]. Food insecurity is caused by inadequate food production; therefore, global warming and climate change are considered a threat to food production and agriculture [7]. In developing countries such as Lao People's Democratic Republic and Thailand edible insects are providing livelihood opportunities such as income and employment for a household that is food insecure [8]. In South Africa, it has been reported that $28.3 \%$ of households are at risk of food insecurity, while $26 \%$ are food insecure [6]. Furthermore, the general household survey reported that $10.6 \%$ of adults and $12.2 \%$ of children in South Africa were always or sometimes hungry [9]. This is a concern because one of the sustainable development goals of the United Nations is to improve and achieve food security. Innovative changes in food production are needed to address the food insecurity challenges that are facing the rapidly growing human population [10]. Therefore, households should be educated to consume more diverse and nutritionally adequate foods [9]. Yellow mealworms or edible insects in general, on their own without other ingredients do not guarantee food security for a household, however, their inclusion could play a role on household food security composite indicator as sources of average supply of protein of animal origin.

Insect meal in the feed industry, regardless of how important it is to animals, is still at an early stage of adoption by farmers and the commercial animal feed industry. However, considering the increase in feed prices, the large ecological footprint of conventional feeds and other factors, there is a need for alternative ingredients. Climate change and global warming play a key role in changing farming activities and affecting household food security. South Africa and many other countries are not immune to the adverse effects of climate change. In 2008, researchers at Stanford University projected that South Africa could lose more than $30 \%$ of maize production from now to 2030 and maize is the country's staple diet and is used as part of the important ingredient in animal feed. Therefore, The use of insects in poultry feeds can play a role in managing some key elements of sustainable development goals such as alleviating poverty (1), zero hunger (2) and gender equality (5). Furthermore, feeding chickens with insects could improve the livelihood of smallholder farmers, contribute to a circular economy and improve food security [11].
Several works of literature have proven that yellow mealworm has the potential to be used as an alternative source of protein in animal diets [12-17], although other insects such as cockroaches, termites, crickets, earthworms, grasshoppers and black soldier flies can be included in animal feeds [18-23]. Most of the insects are harvested from the wild using traditional methods which are unsustainable [24]. However, mealworms have the advantage of being easy to breed and they do not require a large area for production and commercialisation. Mealworms lay about 400-500 eggs on average, their incubation period is between 4 and 34 days, and the hatchability rate of the eggs is about 70\% [12]. Furthermore, the larva can be harvested before it turns into a pupa and be given to chickens with other ingredients. There are different substrates that can be used to rear mealworms. Wheat bran is the most commonly used substrates for rearing mealworms [25]. Mealworms can be reared in a climatecontrolled environment where light, relative humidity and temperature can be controlled and monitored. In addition, the nutritive value of mealworm is comparable to that of soya bean-thus, a good source of amino acids, fatty acids and micronutrients [14].

The use of yellow mealworms in animal feed can improve the sustainability of poultry diets and meet the ever-growing demand for animal protein [12]. Moreover, mealworms produce much less greenhouse gas as compared to other animals [26]. Free-range indigenous chickens have been eating insects for ages and most smallholder farmers are aware of this behaviour [19]. Recently, several organisations have started to commercially produce different types of insects as animal feeds. However, it is not clearly understood how farmers perceive this phenomenon. A sizable number of consumers reported to be ready to incorporate insects into animal feeds and to eat products such as chocolate or biscuits that were made using insects such as grasshoppers [27]. Consumers in Belgium were reported to be willing to accept the use of insects as poultry feeds [28]. In Uganda it was found that feed traders, processors and poultry farmers were willing to accept insects as an alternative source of protein in poultry diets [18]. In addition, insects such as grasshoppers, cockroaches, termites and white ants were most preferred by poultry farmers to rear and use for feeding poultry [18]. In the Eastern Cape province of South Africa, it was discovered that most farmers were concerned about the health risks associated with feeding earthworms to chickens. Nevertheless, the study concluded that farmers had a positive attitude towards the use of earthworms as a protein supplement for their chickens [29]. It is of paramount importance to note that the point at which a new idea is adopted depends on its characteristics. These characteristics affect the adoption 
of an innovation and can be classified as relative advantage, compatibility, complexity, trialability and observability [30].

Most studies conducted on the adoption of insects as poultry feed focused on earthworms, grasshoppers, termites and insects in general $[18,27,28]$. In recent years, a growing number of studies have concentrated on the replacement of traditional protein ingredients in poultry diets. However, not much research has been conducted on the acceptability unconventional ingredients such as insects amongst the farmers. Although the acceptability of insects as feed is still limited, the feasibility of insect-based products is increasingly being investigated and products are being developed [31]. However, it is unknown whether smallholder poultry farmers in South Africa will accept the inclusion of yellow mealworms in poultry diets. The current study intends to fill this gap by investigating the willingness of small-scale poultry farmers to adopt the use of yellow mealworm in the poultry diet, as well as factors influencing their decisions.

\section{Materials and methods}

\section{Study site}

The study was conducted in the City of Tshwane Metropolitan Municipality in the Gauteng province of South Africa (Fig. 1). The geographical location of the area lies along longitude $28^{\circ} 09^{\prime} 60.00^{\prime \prime} \mathrm{E}$ and latitude $-25^{\circ} 39^{\prime}$ 59.99" S at an altitude of $1339 \mathrm{~m}$ above sea level. Tshwane has an average annual rainfall of $573 \mathrm{~mm}$, with the most rain occurring in the summer season (November to January) and sometimes overlapping to autumn (February to April). The mean annual temperature of the area is about $18.7^{\circ} \mathrm{C}$

This area was relevant for investigating the willingness to adopt mealworms in the chicken feed because it is characterised by a growing number of small-scale poultry farmers, who normally buy spent hens/layers and broilers from local commercial farmers and sell them for meat consumption to local communities, mainly in the townships and alongside roads leading to residential areas. The researcher visited the respondents on their smallholdings or at their market stalls. Areas that formed part of the study are Winterveldt, Soshanguve, Ga-Rankuwa, Akasia, Mamelodi, Irene, Atteridgeville, Bronkhorstspruit, Refilwe and Cullinan. The aforementioned study areas were chosen because they are dominated by smallscale poultry farmers in the city due to high population.

\section{Sampling procedure and data collection}

According to the information received from the Provincial Ministry of Agriculture's regional office in the City of Tshwane, there were about 163 poultry farmers

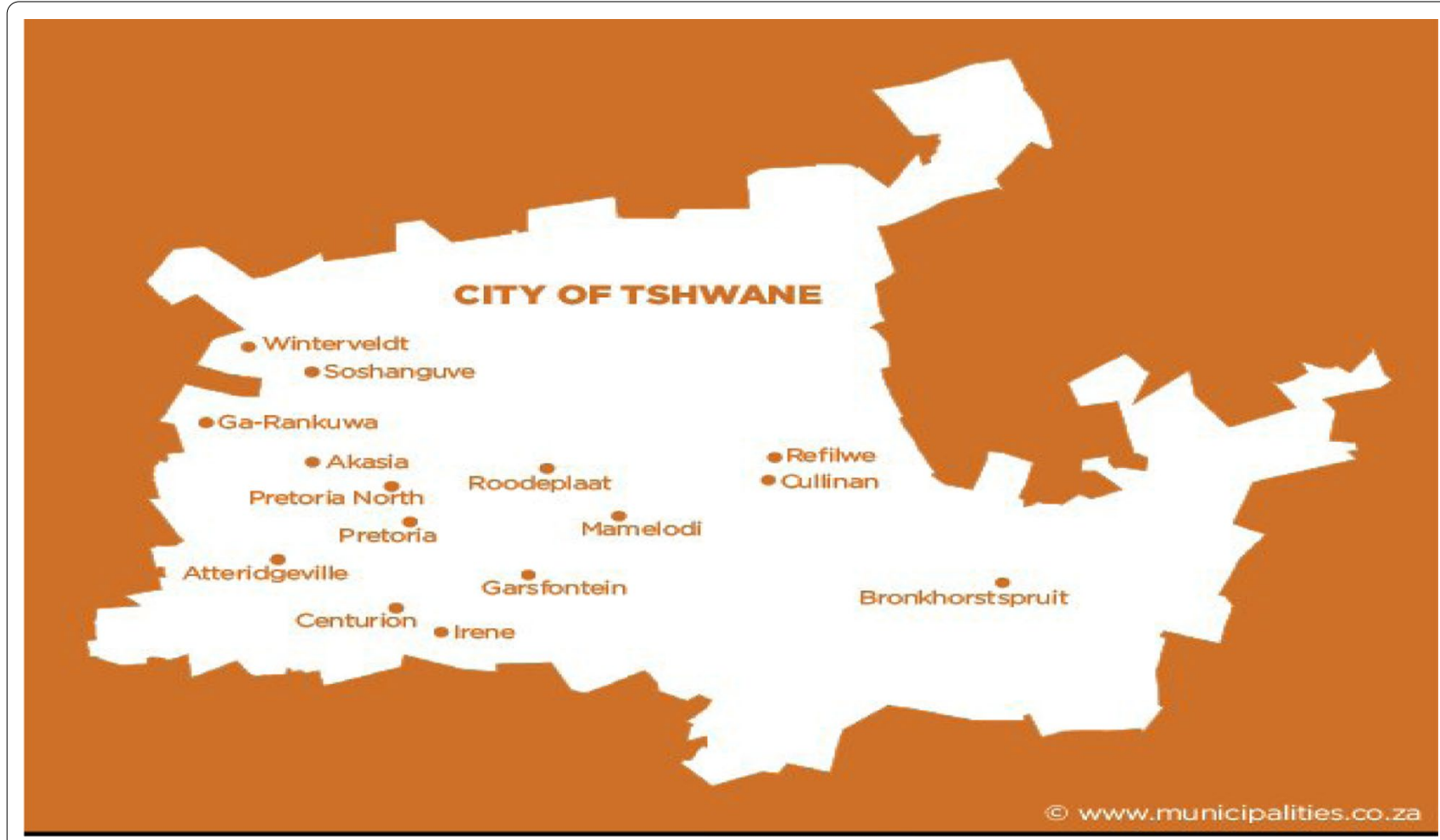

Fig. 1 City of Tshwane Metropolitan Municipality map [32] 
in the Municipality who receive government extension and advisory services. However, during data collection and interaction with farmers it was discovered that there were farmers who did not appear in the records of the agricultural regional office in the City, especially those who purchased mature chickens and sold them in townships. Furthermore, some of the poultry farms were dysfunctional, whereas some farmers declined to participate in the study because of unknown reasons. As a result, the snowball sampling method was adopted whereby interviewed farmers were requested to refer the researcher to other farmers in their vicinity. Through snowball sampling methods, 107 small-scale poultry farmers were identified and interviewed face to face using semistructured survey questionnaires. After interviewing the aforementioned number of farmers, saturation was reached because there were no other farmers available to participate in the study. A sample size of 107 participants was therefore considered a fair representation of farmers in the study area because statistical conclusion can be drawn from such a number of participants. The participants who formed part of the study resided in different communities (formal and informal) within Tshwane Metro.

Permission to conduct this study was sought from the Gauteng Provincial Department of Agriculture and Rural Development. Furthermore, the research was approved by the Human Research Ethics Committee of the College of Agriculture and Environmental Sciences at the University of South Africa, with ethical clearance number: 2019/ CAES_HREC/138. The interviews were conducted only after consent forms had been signed, indicating the participants' willingness to be part of the study. The structured questionnaire comprised three sections, namely socio-demographic characteristics, awareness about mealworms and willingness to adopt yellow mealwormbased chicken feed. Data were collected through face-toface interviews at smallholdings or at market stalls of the respondents. The participants were interviewed about their willingness to adopt yellow mealworms as feed for chickens. The question expected an answer of Yes, which was equated to 1 , or No, which was captured as 0 . Farmers were asked about their attitude towards chickens that were reared using yellow mealworms instead of conventional feed; the purpose was to determine whether they would consume meat from such chickens or not. The answer to the question was captured on a rating scale of $1=$ do not agree, $2=$ not sure and $3=$ agree.

\section{Statistical analysis}

Data collected were analysed using IBM SPSS version 25 [33]. Frequencies were used to analyse the demographic characteristics and project description of the respondents. Furthermore, a binary logistic regression model was used to determine factors that influence farmers' willingness to adopt mealworm as chicken feed. The backward stepwise regression method was used to eliminate the variables from the regression model to find a reduced model that best explains the data. The logistic model is specified as follows:

$$
\mathrm{Zi}=\ln \left(\frac{\mathrm{Pi}}{1-\mathrm{Pi}}\right)=\beta_{0}+\beta_{1} \mathrm{X}_{1 \mathrm{i}}+\beta_{2} \mathrm{X}_{2 \mathrm{i}}+\ldots \beta_{\mathrm{k}} \mathrm{X}_{\mathrm{ki}}+\mathrm{U}_{\mathrm{i}}
$$

where $P i$ is the probability of a poultry farmer adopting mealworm as chicken feed, $[1-P i]$ is the probability of a farmer not adopting mealworm as chicken feed, $\beta_{0}$ is the intercept, $\beta_{1 . .} \beta_{13}$ is the regression coefficient of predictors, $X_{1 . . .} X_{12}$ the predictor variables, and $U$ the random residual error.

In this study, the explanatory (independent) variables used in the model included:

$X 1$ Gender of the head ( $1=$ Male, $2=$ Female) .

$X 2$ Age of the household head $(1 \leq 35,2=36-45$, $3=46-55,4=56-65,5 \geq 66$ ).

$X 3$ Education level of the household head $(1=$ no formal education, $2=$ primary, $3=$ secondary, $4=$ tertiary).

$X 4$ Annual farm net income $(1=100-3500$, $2=3501-10,000,3=10,001-20,000,4=20,001-30,000$, $5 \geq 30,001$ ).

$X 5$ Flock size $(1=1-99,2=100-300,3=301-600$, $4=601-900,5=901-1200)$.

$X 6$ Starter feeds $(1=$ yes, $0=$ no).

$X 7$ Grower feeds $(1=$ yes, $0=$ no $)$.

$X 8$ Finisher feeds $(1=$ yes, $0=$ no).

$X 9$ Mixed corn feeds $(1=$ yes, $0=$ no).

$X 10$ Knowledge about mealworms $(1=$ yes, $0=$ no).

$X 11$ Willingness to eat insect-fed chicken $(1=$ do not agree, $2=$ not sure, $3=$ agree).

$X 12$ Access to extension services $(1=$ never, $2=$ rarely, $3=$ sometimes, $4=$ very often, $5=$ always).

X13 Annual feed costs (estimated feed costs per farm/ household).

The explanatory variables listed above were chosen because they play an important role in the sustainability of poultry production. Furthermore, such factors can reliably predict whether farmers will accept alternative commercial animal feed made from uncommon ingredients such as insects.

\section{Results}

\section{Socio-demographic characteristics}

Farmers' demographic and socio-economic characteristics are presented in Table 1. The results in Table 1 show that most of the respondents were male (60.7\%), most of whom (47.7\%) were married. The dominant group was in the age group of $36-45$ years (34.6\%), whereas 
Table 1 Socio-demographic characteristics of farmers

\begin{tabular}{|c|c|c|c|}
\hline Characteristics & Status & Frequency & Percentage \\
\hline \multirow[t]{2}{*}{ Gender } & Male & 65 & 60.7 \\
\hline & Female & 42 & 39.3 \\
\hline \multirow[t]{4}{*}{ Marital status } & Married & 51 & 47.7 \\
\hline & Single & 42 & 39.3 \\
\hline & Divorced & 6 & 5.6 \\
\hline & Widowed & 8 & 7.4 \\
\hline \multirow[t]{5}{*}{ Age } & $<35$ & 30 & 28 \\
\hline & $36-45$ & 37 & 34.6 \\
\hline & $46-55$ & 24 & 22.4 \\
\hline & $56-65$ & 10 & 9.3 \\
\hline & $66>$ & 6 & 5.6 \\
\hline \multirow[t]{4}{*}{ Education } & No formal education & 9 & 8.4 \\
\hline & Primary & 23 & 21.5 \\
\hline & Secondary & 65 & 60.7 \\
\hline & Tertiary & 10 & 9.3 \\
\hline \multirow[t]{4}{*}{ Farming activity } & Broiler & 26 & 24.3 \\
\hline & Layer & 22 & 20.6 \\
\hline & Broiler and layer & 59 & 55.1 \\
\hline & Indigenous & 0 & 0 \\
\hline \multirow[t]{3}{*}{ Type of poultry house } & Climate controlled & 0 & 0 \\
\hline & Open-sided & 8 & 7.5 \\
\hline & Organised material & 99 & 92.5 \\
\hline \multirow[t]{6}{*}{ Flock size } & $1-99$ & 39 & 36.4 \\
\hline & $100-300$ & 44 & 41.1 \\
\hline & $301-600$ & 14 & 13.1 \\
\hline & $601-900$ & 6 & 5.6 \\
\hline & $901-1200$ & 3 & 2.8 \\
\hline & $1201-3500$ & 1 & 0.9 \\
\hline \multirow{5}{*}{$\begin{array}{l}\text { Annual poultry net } \\
\text { income }\end{array}$} & R100-3500 & 18 & 16.8 \\
\hline & R3501-10,000 & 46 & 43 \\
\hline & $R 10,001-R 20,000$ & 21 & 19.6 \\
\hline & $R 20,001-R 30,000$ & 10 & 9.3 \\
\hline & $>\mathrm{R} 30,000$ & 12 & 11.2 \\
\hline
\end{tabular}

$28 \%$ were younger than 35 years old. More than half (60.7\%) of the respondents had secondary education, which implies that most of the farmers in the study area could read and write. About $47.7 \%$ had spousal support because they were married.

The results in Table 1 also indicate that more than half $(55.1 \%)$ of the respondents had both broiler and layer enterprises, with a flock size of up to 3500 . The poultry houses/structures were constructed from bricks and mortar, iron sheets or chicken cages. None of the small-scale poultry farmers interviewed had a climate-controlled poultry house. The results indicate that less than half $(43.0 \%)$ of the farmers made between R3501 and R10,000 per annum (U\$233 and U\$666 per annum). Income level plays an important role in farming, as it enables the farmer to decide whether to continue investing in an activity or not.

Farmers' willingness to adopt mealworms as poultry feed Table 2 summarises the comparison of characteristics of the respondents willing and unwilling to adopt yellow mealworm as chicken feed. The results show that almost three-quarters $(72.0 \%)$ of the respondents, most of whom were male (52.3\%), were willing to adopt yellow mealworm as chicken feed. In addition, most of the respondents who were willing to adopt mealworms were married (34.6\%), in the age group of 36-45 years $(27.1 \%)$ and had secondary education (48.6\%). The willingness to adopt mealworm as part of the important ingredients in poultry feed could be influenced by economic and environmental factors. In the current study, farmers held the perception that using mealworm in the poultry diet would reduce their feed costs and increase profit. Some of the farmers were optimistic about the adoption of unconventional poultry diets containing mealworm, even though the benefits were unknown to them. Farmers who are not willing to adopt yellow mealworm as part of a poultry diet could also be influenced by factors related to lack of knowledge about mealworms.

Of the 107 small-scale poultry farmers who were interviewed, $51.4 \%$ agreed that they would eat chicken that was reared using yellow mealworm, 25.2\% disagreed and $23.4 \%$ were not sure. Farmers were further asked if they were willing to rear mealworms on their respective smallholdings (farms) and use them to feed their chickens. $63.5 \%$ agreed that they would adopt this innovation of rearing yellow mealworms on their farms. Furthermore, farmers were asked about the number of times they had contact with the extension agents or agricultural advisor or animal welfare agents. Nearly two-thirds (62.0\%) of the respondents reported that they never had contact with extension agents. This is corroborated by the fact that more than two-thirds $(>66.6 \%)$ of the farmers were not listed in the records of the regional extension office. Such farmers may be those who purchase mature chickens and sell them in the townships and other residential areas.

\section{Farmers' awareness or knowledge of insects used as poultry feed}

The respondents' awareness of the use of insects as poultry feed was also determined. The results reveal that most of the smallholder poultry farmers (78.0\%) were not aware that yellow mealworms could be used as chicken feed. Farmers were presented with mealworm beetles, larvae and pupae in a transparent container for identification purposes and to create awareness. The majority 
Table 2 Comparison of characteristics of the respondents willing and not willing to adopt mealworm as poultry feed $(n=107)$

\begin{tabular}{|c|c|c|c|c|c|}
\hline \multirow[t]{2}{*}{ Characteristics } & \multirow[t]{2}{*}{ Status } & \multicolumn{2}{|c|}{ Willing to adopt (Yes) } & \multicolumn{2}{|c|}{ Unwilling to adopt (No) } \\
\hline & & Frequency & Percentage & Frequency & Percentage \\
\hline \multirow[t]{3}{*}{ Gender } & Male & 56 & 52.3 & 9 & 8.4 \\
\hline & Female & 21 & 19.6 & 21 & 19.6 \\
\hline & Total & 77 & 72 & 30 & 28 \\
\hline \multirow[t]{5}{*}{ Marital status } & Married & 37 & 34.6 & 14 & 13.1 \\
\hline & Single & 33 & 30.8 & 9 & 8.4 \\
\hline & Widow/er & 3 & 2.8 & 3 & 2.8 \\
\hline & Divorced & 4 & 3.7 & 4 & 3.7 \\
\hline & Total & 77 & 72 & 30 & 28 \\
\hline \multirow[t]{6}{*}{ Age } & $<35$ & 22 & 20.6 & 8 & 7.5 \\
\hline & $36-45$ & 29 & 27.1 & 8 & 7.5 \\
\hline & $46-55$ & 18 & 16.8 & 6 & 5.6 \\
\hline & $56-65$ & 5 & 4.7 & 5 & 4.7 \\
\hline & $66->$ & 3 & 2.8 & 3 & 2.8 \\
\hline & Total & 77 & 72 & 30 & 28 \\
\hline \multirow[t]{5}{*}{ Education } & No formal education & 2 & 1.9 & 7 & 6.5 \\
\hline & Primary & 13 & 12.1 & 10 & 9.3 \\
\hline & Secondary & 52 & 48.6 & 13 & 12.1 \\
\hline & Tertiary & 10 & 9.3 & 0 & 0 \\
\hline & Total & 77 & 72 & 30 & 28 \\
\hline
\end{tabular}

Table 3 Results of logistic regression model of the willingness to adopt mealworm as poultry feed $(N=107)$

\begin{tabular}{|c|c|c|c|c|c|}
\hline Variable & $B$ & SE & Wald & Sig & $\operatorname{EXP}(B)$ \\
\hline Gender & -0.563 & 0.715 & 0.620 & 0.431 & 0.570 \\
\hline Age & -0.592 & 0.288 & 4.228 & $0.040^{*}$ & 0.553 \\
\hline Education & 1.568 & 0.506 & 9.602 & $0.002^{* *}$ & 4.798 \\
\hline Annual net income & 0.397 & 0.371 & 1.145 & 0.285 & 1.488 \\
\hline Flock size & 0.105 & 0.398 & 0.070 & 0.791 & 1.111 \\
\hline Starter feeds & 3.288 & 1.707 & 3.711 & 0.054 & 26.799 \\
\hline Grower feeds & 0.786 & 0.868 & 0.819 & 0.366 & 2.194 \\
\hline Finisher feeds & 1.509 & 0.723 & 4.352 & $0.037^{*}$ & 4.521 \\
\hline Mixed corn feeds & 2.518 & 0.884 & 8.114 & $0.004^{* *}$ & 12.409 \\
\hline Knowledge about mealworms & -0.707 & 0.876 & 0.651 & 0.420 & 0.493 \\
\hline Willing to eat insect-fed chicken & 0.743 & 0.443 & 2.815 & 0.093 & 0.493 \\
\hline Access to extension and advisory services & -0.414 & 0.351 & 1.394 & 0.238 & 0.661 \\
\hline Distance to feed store & 0.195 & 0.350 & 0.312 & 0.577 & 1.215 \\
\hline Annual feed costs & 0.000 & 0.000 & 0.734 & 0.392 & 1.000 \\
\hline Constant & -5.028 & 2.747 & 3.351 & 0.067 & 0.007 \\
\hline
\end{tabular}

${ }^{*} P \leq 0.05$ and ${ }^{* *} P \leq 0.01$ 
(85.0\%) of the respondents had never seen yellow mealworms and only a few (15.0\%) had.

\section{Factors influencing farmers' willingness to adopt yellow mealworm as poultry feed}

The results of the binary logistic regression are presented in Table 3. The explanatory variables that were positive/ negative and significant will be interpreted. The results show that ten out of fourteen variables positively influenced the willingness of the respondents to adopt mealworm as poultry feed. However, only education level, age, finisher feeds and usage of mixed corn were statistically significant at the 5\% interval level, whereas starter feeds, and consumption of insect-fed chicken were significant at $10 \%$. The values of the null model with no predictors were $100 \%$ and $0 \%$ for likely to adopt and unlikely to adopt, respectively, with an overall percentage of $71.95 \%$. The predicted chance of adopting yellow mealworm was 2.566; this value was achieved by dividing 77 (willing to adopt) by 30 (not willing) $(77 / 30=2.566)$. The Chi-square value of omnibus tests of model coefficient was 49.226 with a $P$-value of 0.000 ; this shows that the whole model fits the data significantly better than an empty model or a model without predictors. Furthermore, the classification table shows that the findings of the three predictors were 91.5\% of the observed respondents who would adopt and $73.9 \%$ who would not adopt a yellow mealworm chicken diet, with an overall percentage of $85.7 \%$. Therefore, the null model has a lower value, which implies that it can predict the decision better than the model summary. The values for Cox and Snell R-square and Nagelkerke $R$-square were 0.369 and 0.531 , respectively. This implies that there is a 37 to $53 \%$ variation of the probability that farmers will adopt yellow mealworm as chicken diet.

The education level of the respondents was positive $(\beta=1.568)$ and statistically significant at the $1 \%$ interval. This implies that farmers with a higher education level were more willing to adopt mealworm as poultry feed, with other factors held constant. The coefficient of farmers using mixed corn to feed their chickens had a positive $(\beta=2.518)$ and significant influence on farmers' willingness to adopt mealworm as poultry feed. This indicates that farmers who used mixed corn to feed their chickens were more willing to adopt mealworm as poultry feed, all things being equal. Furthermore, farmers' age had a negative $(\beta=-0.592)$ and significant influence on the respondents' willingness to use mealworm to feed their chickens, at a $5 \%$ significance interval. This implies that as farmers' age increased, their willingness to adopt mealworm as poultry feed decreased, all factors being equal.

The type of feed the farmer used (finisher) was positive $(\beta=1.509)$ and statistically significant at a $5 \%$ interval. This implies that farmers who used finisher feed were more willing to adopt mealworm in the poultry diet, with other factors held constant.

\section{Discussion}

The results obtained in this study indicate that the willingness of farmers to adopt yellow mealworms is strongly influenced by the education level of the farmers, which was the most significant factor. Educated farmers are more likely to make informed decisions because they can read, write and interpret information. According to Kielbasa [34], education plays a key role in influencing a farmer's response towards innovation. This was evident in the current study because poultry farmers who had higher educational levels envisaged the benefits of using yellow mealworm as an alternative protein source in poultry feeds. As reported by O'Donoghue [35], in most cases early adopters of innovation are likely to have a formal agricultural education background. These results are in line with those of Espinosa-Diaz [36], who indicated that the education level of the farmer plays a determining role in the person's intention to adopt insect farming for animal feed. It could be evidence that farmers who are more educated are willing to adopt new agricultural technologies than those with a low education background. The adoption of new technologies is influenced by many factors [30]. The theory of diffusion is relevant to this study because the idea of using mealworm as poultry feed, particularly for exotic breeds, is relatively new. However, understanding farmers' perception of the new technology is crucial because they may evaluate it differently than scientists $[37,38]$. In most cases agricultural innovations are poorly understood and this affects the adoption phase [39].

The attitude of farmers towards the use of insects as animal feed has been studied by several researchers [13, $28,29,36]$. The willingness of small-scale farmers to adopt mealworm as poultry feed may result in lowering dependency on soya bean and fishmeal as the only protein supplement in poultry feeds. In the current study a considerable number of farmers showed an interest in rearing mealworms on their farm to feed their chickens. The results are in line with previous studies which found that the use of insects in animal feed can lower reliance on conventional poultry feed $[4,36,40]$. Furthermore, it could also have an impact on the livelihood of small-scale poultry farmers by reducing transaction costs and possibly increasing farm income. However, mealworm meal is still not regarded as a competitive protein source-due to its current market price compared to conventional feeds. Farmers in some areas, however, consider insects such as termites as a very useful protein source for poultry [19]. The inclusion of mealworm in broiler diets is also acceptable as a protein feedstuff in some areas [41]. Therefore, 
finding profitable ways to introduce this phenomenon will have a long-lasting economic benefit for all stakeholders. It is therefore imperative to determine the financial viability of using insects such as yellow mealworm as alternative protein source in poultry diets.

The consumption of end products from chickens that were fed mealworms was accepted by half of the poultry farmers in the current study. These outcomes are consistent with the findings of other researchers $[20,26]$. Those who disagreed could be affected by other factors such as customer perception of insect-based chicken, health concerns, and lack of knowledge about the importance of mealworms as chicken feed, or old age and unwillingness to try new things. Furthermore, in South Africa there is no national policy framework regulating the use of insects as animal feeds [42]. As a result, the use of insects as a protein source for poultry has not been popular amongst the farmers because there is no political and administrative will from government. Nonetheless, Adesina [43] has reported that consumers have the power to determine the success or failure of any product; therefore, awareness about the benefits related to insect-based products that are closely related to economic and environmental sustainability is extremely important. Despite lack of a relevant legislation framework in South Africa, the perceptions could change if a large proportion of the farmers are well informed about the economic benefits of using mealworms as protein source for poultry. The unwillingness to adopt mealworm as poultry feed could also emanate from food safety issues related to the microbial quality of mealworms. According to Vandeweyer [31], mealworm sampled from different rearing facilities had microorganisms such as Spiroplasma and Erwinia species. This could have some health implications if food safety guidelines are not adhered to.

It is further noted in this study that nearly half of the younger farmers (18-45 years) were more interested in adopting mealworms as their chicken feed than older farmers ( $>46$ years). It could be interpreted that older farmers are not willing to try new innovations and are thus more conservative/unwilling to take risks [44]. Having younger farmers willing to adopt mealworm as poultry feed is a positive sign for the future of alternative sources of protein for chickens. This is in line with other studies in which the age of the farmer was found to be significant in the person's intention to adopt agricultural innovations or not $[44,45]$. Younger farmers are interested in innovation and they are willing to take the risk [36]. These outcomes were expected, given that mealworms are not common in South Africa and are found mostly at universities and research institutions. This study further revealed that farmers who were using mixed corn to feed their chickens were more willing to adopt mealworms as poultry feed. It has been reported that some poultry farmers prefer their own mixed feed because it is cheaper than commercial feed [18].

Agricultural extension agents are primarily responsible for providing farmers with agricultural information that enhances their knowledge and skills and could thus help in adopting new technologies [38]. Mainly the Ministry of Agriculture through extension agents/agricultural advisors [46] provides the agricultural extension service in South Africa. However, the SPCA (Society for the Prevention of Cruelty to Animals) also plays a key role by teaching farmers about animal welfare $[47,48]$. Most farmers who reported to have been in contact with the extension agents were not willing to adopt mealworm. A contradictory result was reported by other researchers [38, 49-52], namely, that agricultural extension visits significantly affect the adoption of agricultural technologies by farmers.

\section{Conclusion}

In the study it was found that the majority of small-scale poultry farmers in the City of Tshwane Metro were not familiar with mealworms. However, more than twothirds of the farmers, of which most were married men, were willing to adopt yellow mealworm as alternative protein source for their poultry. Nearly half of the farmers who were willing to feed their poultry (birds) with yellow mealworm had secondary education. This was corroborated by the findings of binary regression which showed that highly educated people were more likely to adopt yellow mealworm as an alternative poultry feed. It is thus recommended that awareness about the nutritional and economic benefits of yellow mealworm for poultry should be created amongst older farmers (above 46 years) who have primary education but no formal education. On the other hand, age had a negative and significant influence on farmers' willingness to accept the inclusion of yellow mealworm in poultry diets. That is supported by large proportion of farmers aged between 18 and 45 who were willing to adopt poultry feeds that contained yellow mealworm as a source of protein. Therefore, it is important to educate older farmers about the benefits of including insects such as yellow mealworm and others as a protein source in animal feeds. Such awareness programmes can be implemented through extension agents. As a result, a well-represented number of farmers, mainly those with secondary education and below the age of 45 , were willing to adopt mealworm as their poultry feed. Furthermore, early adopters of mealworms as poultry feed should be profiled so that communication strategies can be developed to deal with the fears and negative perceptions towards poultry feed that contains mealworm as a protein source. Moreover, this research could 
provide insight for private companies and policymakers into developing strategies to increase the acceptance and commercialisation of mealworms as an alternative protein source in poultry feed. It is also recommended that an experimental study should be conducted to determine the feasibility of including live or dried yellow mealworm as alternative source of protein in poultry feed, with specific reference to nutritional benefits, growth of birds and profitability. Such study will enhance the acceptability and adoption rate of poultry feed containing yellow mealworm. In addition, farmers feeding their birds with mixed corn showed significant interest in adopting mealworm as poultry feed. This proves that some of the poultry farmers were aware of the large quantity of protein found in insets such as yellow mealworm compared to mixed corn (maize). It is therefore recommended that experimental research be conducted about using yellow mealworm as protein source in poultry feeds, incorporating mixed corn in the diet given to the birds. That is more likely to enhance the adoption rate of poultry diets with yellow mealworm and mixed corn (maize) as sources of protein.

\section{Abbreviations}

DAFF: Department of Agriculture, Fisheries and Forestry; SPCA: Society for prevention of cruelty to animals; USA: United States of America.

\section{Acknowledgements \\ Thank you to all Tshwane small-scale poultry farmers who participated in this study}

\section{Authors' contributions}

All authors have read and agree to the published version of the manuscript. Conceptualisation: MM and LS; methodology: MM; software: MM and LS; formal analysis: MM and LS; writing: LS; writing — review and editing: MM and MM. All authors read and approved the final manuscript.

\section{Funding}

This research received no external funding.

\section{Availability of data and materials}

The author attaches the data set used for the analysis along with this manuscript in SPSS file version 25 (Selaledi SPSS DATA and Selaledi output1 (3).

\section{Ethics approval and consent to participate}

Permission to conduct this study was sought from the Gauteng Provincial Department of Agriculture and Rural Development. Furthermore, the research was approved by the Human Research Ethics Committee of the College of Agriculture and Environmental Sciences at the University of South Africa, with ethical clearance number: 2019/CAES_HREC/138.

\section{Consent for publication}

Not applicable.

\section{Competing interests}

The authors declare no conflict of interest in the collection, analysis, or interpretation of data, in the writing of the manuscript, or in the decision to publish the results.

\section{Author details}

${ }^{1}$ College of Agriculture and Environmental Sciences, University of South Africa, Unisa Science Campus, Florida, Johannesburg, South Africa.
${ }^{2}$ Department of Zoology and Entomology, Mammal Research Institute, Faculty of Natural and Agricultural Sciences, University of Pretoria, Hatfield, Cityof Tshwane, South Africa.

Received: 25 June 2020 Accepted: 28 January 2021

Published online: 18 May 2021

\section{References}

1. Department of Agriculture, Forestry \& Fisheries, 2017. South African animal feeds market analysis report. https://www.nda.agric.za/doaDev/ sideMenu/Marketing/Annual\%20Publications/Commodity\%20Profiles/ field\%20crops/South\%20African\%20Animal\%20Feeds\%20Market\%20Ana lysis\%20Report\%202017.pdf Accessed 12 Dec 2019.

2. Department of Agriculture, Forestry \& Fisheries, 2018. South African animal feeds market analysis report. https://www.nda.agric.za/doaDev/ sideMenu/Marketing/Annual\%20Publications/Commodity\%20Profiles/ field\%20crops/South\%20African\%20Animal\%20Feeds\%20Market\%20Ana lysi\%20Report\%202018.pdf Accessed 05 Jan 2020.

3. Niassy S, Affognon HD, Fiaboe KKM, Akutse KS, Tanga CM, Ekesi S. Some key elements on entomophagy in Africa: culture, gender and belief. J Insects Food Feed. 2016;2(3):139-44.

4. Chaalala S, Leplat A, Makkar H. Importance of Insects for Use as Animal Feed in Low-Income Countries. In Edible Insects in Sustainable Food Systems. Springer, Cham. 2018. pp. 303-319

5. Van Huis A. Edible insects contributing to food security? Agric Food Secur. 2015;4:20. https://doi.org/10.1186/s40066-015-0041-5.

6. Santeramo FG. On the composite indicators for food security: decisions matter! Food Rev Int. 2015;31(1):63-73.

7. Sasson A. Food security for Africa: an urgent global challenge. Agric Food Security. 2012;1(1):1-16.

8. Durst PB, Hanboonsong Y. Small-scale production of edible insects for enhanced food security and rural livelihoods: experience from Thailand and Lao People's Democratic Republic. J Insects Food Feed. 2015;1(1):25-31.

9. Altman M, Hart TG, Jacobs PT. Household food security status in South Africa. Agrekon. 2009;48(4):345-61.

10. Dicke M. Insects as feed and the sustainable development goals. J Insects Food Feed. 2018;4(3):147-56

11. Chia SY, Tanga CM, van Loon JJ, Dicke M. Insects for sustainable animal feed: inclusive business models involving smallholder farmers. Curr Opin Environ Sustainabil. 2019;41:23-30.

12. Selaledi L, Mbajiorgu CA, Mabelebele $M$. The use of yellow mealworm ( $T$. molitor) as alternative source of protein in poultry diets: a review. Tropic Anim Health Product. 2019;52:1-10.

13. Van Huis A. Potential of insects as food and feed in assuring food security. Annu Rev Entomol. 2013;58:563-83.

14. Grau T, Vilcinskas A, Joop G. Sustainable farming of the mealworm Tenebrio molitor for the production of food and feed. Zeitschrift für Naturforschung C. 2017;72(9-10):337-49.

15. Ballitoc DA, Sun S. Ground yellow mealworms (Tenebrio molitor L.) feed supplementation improves growth performance and carcass yield characteristics in broilers. Open Sci Reposit Agric. 2013;18:e23050425.

16. Biasato I, De Marco M, Rotolo L, Renna M, Lussiana C, Dabbou S, Capucchio MT, Biasibetti E, Costa P, Gai F, Pozzo L. Effects of dietary Tenebrio molitor meal inclusion in free-range chickens. J Anim Physiol Anim Nutrit. 2016;100(6):1104-12.

17. Bovera F, Loponte R, Marono S, Piccolo G, Parisi G, laconisi V, Gasco L, Nizza A. Use of Tenebrio molitor larvae meal as protein source in broiler diet: effect on growth performance, nutrient digestibility, and carcass and meat traits. J Anim Sci. 2016;94(2):639-47.

18. Sebatta C, Ssepuuya G, Sikahwa E, Mugisha J, Diiro G, Sengendo M, Fuuna P, Fiaboe KKM, Nakimbugwe D. Farmers' acceptance of insects as an alternative protein source in poultry feeds. Int J Agric Res Innovat Technol. 2018;8(2):32-41.

19. Boafo HA, Affedzie-Obresi S, Gbemavo DSJC, Clottey VA, Nkegbe E, AduAboagye $\mathrm{G}$, Kenis M. Use of termites by farmers as poultry feed in Ghana. Insects. 2019;10(3):69.

20. Sogbesan AO, Ugwumba AAA. Nutritional evaluation of termite (Macrotermes subhyalinus) meal as animal protein supplements in the diets of 
Heterobranchus longifilis (Valenciennes, 1840) fingerlings. Turkish J Fisheries Aquatic Sci. 2008;8(1):149-58.

21. Kelemu S, Niassy S, Torto B, Fiaboe K, Affognon H, Tonnang H, Maniania NK, Ekesi S. African edible insects for food and feed: inventory, diversity, commonalities and contribution to food security. J Insects Food Feed. 2015;1 (2):103-19.

22. Rapatsa MM, Moyo NA. Evaluation of Imbrasia belina meal as a fishmeal substitute in Oreochromis mossambicus diets: growth performance, histological analysis and enzyme activity. Aquaculture Rep. 2017;5:18-26.

23. Józefiak D, Józefiak A, Kierończyk B, Rawski M, Świątkiewicz S, Długosz J, Engberg RM. Insects-a natural nutrient source for poultry-a review. Ann Anim Sci. 2016;16(2):297-313.

24. Moon SJ, Lee JW. Current views on insect feed and its future. Entomol Res. 2015;45(6):283-5.

25. Van Zyl C, Malan AP. Cost-effective culturing of Galleria mellonella and Tenebrio molitor and entomopathogenic nematode production in various hosts. African Entomol. 2015;23(2):361-75.

26. Oonincx DG, De Boer IJ. Environmental impact of the production of mealworms as a protein source for humans-a life cycle assessment. PLoS ONE. 2012;7(12):e51145.

27. Laureati M, Proserpio C, Jucker C, Savoldelli S. New sustainable protein sources: Consumers' willingness to adopt insects as feed and food. Italian J Food Sci. 2016;28(4):661.

28. Verbeke W, Spranghers T, De Clercq P, De Smet S, Sas B, Eeckhout M. Insects in animal feed: acceptance and its determinants among farmers, agriculture sector stakeholders and citizens. Anim Feed Sci Technol. 2015;204:72-87.

29. Gunya B, Idamokoro EM, Aliber M. Farmers' attitude towards the use of earthworms as a protein feed source for village chickens. J Insects Food Feed. 2019:5(3):1-6.

30. Rogers EM. Diffusion of innovation. 5th ed. New York: Free Press; 2003.

31. Vandeweyer D, Crauwels S, Lievens B, Van Campenhout L. Metagenetic analysis of the bacterial communities of edible insects from diverse production cycles at industrial rearing companies. Int J Food Microbiol. 2017:261:11-8.

32. The local government handbook., 2016. City of Tshwane Map. Municipalities of South Africa. https//municipalities.co.za/map/3/city-of-tshwanemetro-municipalities. Accessed 15 Jan 2020

33. IBM Corp. Released 2017. IBM SPSS Statistics for Windows, Version 25.0. Armonk, NY: IBM Corp.

34. Kielbasa B. Education as a determinant of the implementation of innovation in agriculture in the light of empirical research. Roczniki Naukowe Stowarzyszenia Ekonomistów Rolnictwa i Agrobiznesu. 2016;18(1):4-17.

35. O'Donoghue $\mathrm{C}$, Heanue $\mathrm{K}$. The impact of formal agricultural education on farm level innovation and management practices. J Technol Transfer. 2018:43(4):844-63.

36. Espinosa Diaz, S., 2018. "Determinants of farmers' intention to adopt small scale insect farming practices for animal feed in Columbia. https://lib. ugent.be/fulltxt/RUG01/002/791/246/RUG01-002791246_2019_0001_ AC.pdf: Accessed 15 Jan 2020

37. Kivlin JE, Fliegel FC. Differential perceptions of innovations and rate of adoption. Rural Sociology. 1967;32(1):78.
38. Warku AA. Factors affecting diffusion and adoption of agricultural innovations among farmers in Ethiopia-case study of Ormia Regional State Western Sewa. J Med Biol. 2019;1 (2):54-66.

39. Bandiera O, Rasul I. Social networks and technology adoption in northern Mozambique. Econ J. 2006;1 16(514):869-902.

40. Muthunarayanan V, Arumugam K, Duraisam T. Possibility of eco friendly post consumer waste management. Procedia Environ Sci. 2016;35:416-24.

41. Elahi U, Wang J, Ma YB, Wu SG, Wu J, Qi GH, Zhang HJ. Evaluation of yellow mealworm meal as a protein feedstuff in the diet of broiler chicks. Animals. 2020;10(2):224.

42. Arru B, Furesi R, Gasco L, Madau FA, Pulina P. The introduction of insect meal into fish diet: the first economic analysis on European sea bass farming. Sustainability. 2019;11(6):1697.

43. Niassy S, Ekesi S, Hendriks SL, Haller-Barker A. Legislation for the use of insects as food and feed in the South African context. In Edible insects in sustainable food systems. Cham: Springer. 2018. pp. 457-470

44. Adesina AA, Mbila D, Nkamleu GB, Endamana D. Econometric analysis of the determinants of adoption of alley farming by farmers in the forest zone of southwest Cameroon. Agr Ecosyst Environ. 2000;80(3):255-65.

45. Chi TTN, Yamada R. Factors affecting farmers'adoption of technologies in farming system: a case study in Omon district, Can Tho province, Mekong Delta. Omonrice. 2002;10:94-100.

46. Daxini A, O'Donoghue C, Ryan M, Buckley C, Barnes AP, Daly K. Which factors influence farmers' intentions to adopt nutrient management planning? J Environ Manage. 2018;224:350-60.

47. Davis KE, Terblanche SE. Challenges facing the agricultural extension landscape in South Africa, Quo Vadis? South Afr J Agricu Extens. 2016:44(2):231-47.

48. Sheppard, K. and Widowski, T., 2011. Partnering to Promote Animal Welfare. http://hdl.handle.net/10214/2549 Accessed 20 Jan 2020

49. Wilkins DB, Houseman C, Allan R, Appleby MC, Peeling D, Stevenson P. Animal welfare: the role of non-governmental organisations. Revue scientifique et technique-Office international des épizooties. 2005;24(2):625.

50. Biasato I, Gasco L, De Marco M, Renna M, Rotolo L, Dabbou S, Capucchio MT, Biasibetti E, Tarantola M, Sterpone L, Cavallarin L. Yellow mealworm larvae (Tenebrio molitor) inclusion in diets for male broiler chickens: effects on growth performance, gut morphology, and histological findings. Poult Sci. 2017;97(2):540-8.

51. Veldkamp T, Van Duinkerken G, Van Huis A, Lakemond CMM, Ottevanger E, Bosch G, Van Boekel T. Insects as a Sustainable Feed Ingredient in Pig and Poultry Diets: A Feasibility Study = Insecten als duurzame diervoedergrondstof in varkens-en pluimveevoeders: een haalbaarheidsstudie (No. 638). Wageningen UR Livestock Research. 2012.

52. Nkonya E, Schroeder T, Norman D. Factors affecting adoption of improved maize seed and fertiliser in northern Tanzania. J Agric Econ. 1997;48(1-3):1-12.

\section{Publisher's Note}

Springer Nature remains neutral with regard to jurisdictional claims in published maps and institutional affiliations.

\footnotetext{
Ready to submit your research? Choose BMC and benefit from:

- fast, convenient online submission

- thorough peer review by experienced researchers in your field

- rapid publication on acceptance

- support for research data, including large and complex data types

- gold Open Access which fosters wider collaboration and increased citations

- maximum visibility for your research: over $100 \mathrm{M}$ website views per year
}

At BMC, research is always in progress.

Learn more biomedcentral.com/submissions 